\title{
EKSPRESI THUMOS MISHIMA YUKIO DALAM NOVEL KINKAKUJI
}

\author{
Zaki Ainul Fadli \\ Fakultas Ilmu Budaya Universitas Diponegoro \\ Email: zaki.undip@gmail.com
}

\begin{abstract}
In the social study, there is a concept about strong desire to be recognized by others named thumos. Mishima as a Japanese ultranasionalist have a value about guarding the traditional Japanese values. Among of these values is the absolute position of Japanese emperor in the state. If Mishima's thumos which expressed in the novel linked with his ideology, there is strong similarity between the protagonist's disappointment and Mishima's critics related with the Japanese society. Those assumptions supported by novel's structural aspects.

Keywords : thumos, critics, Japanese society
\end{abstract}

\section{Pendahuluan}

Kinkakuji adalah nama kuil Buddha di Jepang yang berada di kota Kyoto. Kinkakuji dibangun pada tahun 1397 oleh Shogun Ashikaga Yoshimitsu. Kinkakuji pernah dibakar dengan sengaja oleh seorang pendeta muda bernama Hayashi Yoken pada tanggal 2 Juli 1950. Kisah tersebut digunakan sastrawan Mishima Yukio sebagai bahan pembuatan novel Kinkakuji. Di antara karya-karya Mishima, banyak yang menganggap novel Kinkakuji adalah karya tersuksesnya dan merupakan karya yang dijuluki sebagai Mishima's greatest masterpiece. Novel Kinkakuji memperoleh pula penghargaan sastra Yomiuri pada tahun 1957. Novel Kinkakuji menceritakan petualangan pendeta gagap bernama Mizoguchi yang membakar Kinkakuji yang dikaguminya. Kisah dalam novel ini sangat mirip dengan peristiwa yang sebenarnya. Akan tetapi, banyak yang menduga bahwa Mishima menulis novel Kinkakuji untuk mengekspresikan kritiknya terhadap masyarakat Jepang yang pada saat itu yang berada dalam keadaan damai..

Tulisan ini menggunakan pendekatan sosiologi sastra dalam penelaahan teks novel Kinkakuji. Menurut Laurenson dan Swingewood (1972: 13-21) terdapat tiga perspektif berkaitan dengan sosiologi sastra, yaitu: (1) penelitian yang memandang karya sastra sebagai dokumen sosial yang di dalamnya merupakan refleksi situasi pada masa sastra tersebut diciptakan, (2) penelitian yang mengungkap sastra sebagai cermin sosial penulisnya, dan (3) penelitian yang menangkap sastra sebagai manifestasi peristiwa sejarah dan keadaan sosial budaya. Tulisan ini akan menggunakan perspektif yang kedua, yaitu penelitian yang mengungkap sastra sebagai cermin sosial penulisnya. Novel Kinkakuji karya Mishima Yukio merupakan manifestasi dari peristiwa sejarah, karena itu memungkinkan juga untuk menggunakan perspektif yang pertama maupun ketiga. Akan tetapi karena tulisan ini bertujuan untuk mengungkap pemikiran dan ideologi pengarang yang dikaitkan dengan teks di dalam novel Kinkakuji, maka tulisan ini menggunakan perspektif pertama yang lebih tepat digunakan untuk mengungkap permasalahan tersebut. 


\section{Rumusan Permasalahan}

Mishima juga merupakan sastrawan yang dikenal sebagai seorang ultranasionalis. Novel Kinkakuji berlatar waktu Jepang setelah kalah dalam Perang Dunia II. Pemikiran tokoh-tokoh di dalamnya mengenai Jepang, khususnya sang protagonis, memiliki banyak kesamaan dengan pemikiran dan ideologi Mishima Yukio. Dalam tulisan ini akan diungkap mengenai adanya keterkaitan antara pemikiran-pemikiran Mishima tentang Jepang pada masa itu yang terekspresikan di dalam teks sastra Kinkakuji. Dengan kata lain, tulisan ini akan berusaha mengungkap ekspresi thumos Mishima Yukio yang termanifestasikan di dalam novel Kinkakuji.

\section{Definisi Thumos ${ }^{1}$}

Thumos secara fisik mempunyai asosiasi dengan nafas atau darah. Kata ini juga digunakan sebagai konsep untuk mengekspresikan keinginan dan keberanian manusia untuk diakui. Thumos adalah sebuah bentuk nilai atau kesadaran dan mendorong orang-orang untuk mencari pengakuan. Keinginan manusia untuk "diakui" tersebut dinyatakan oleh Plato di dalam buku yang berjudul The Republic. Plato menyebutkan bahwa di dalam jiwa manusia terdapat tiga sisi yaitu sisi hasrat/keinginan, sisi pemikiran/pertimbangan dan satu sisi lagi yang dinamakan "thumos atau thymos". Manusia juga menginginkan pengakuan terhadap nilai-nilai mereka atau nilai-nilai yang mereka percayai. "Thumos" adalah sesuatu yang dibawa manusia sejak lahir.

Setiap orang percaya bahwa dia mempunyai nilai-nilai tertentu. Ketika nilainilai tersebut tidak diakui maka manusia akan marah, dan ketika dia merasa tidak pantas dalam menjalani nilai-nilainya maka dia akan menjadi malu, seperti penilaian yang tepat terhadap nilai kebanggaan. Keinginan untuk diakui dan perasaan marah,

\footnotetext{
${ }^{1}$ Diunduh dan diterjemahkan oleh penulis dari http://en.wikipedia.org/wiki/Thumos.
}

malu atau bangga berasal dari elemen yang esensial dari kepribadian manusia yang menentukan terhadap kehidupan dan terus mempengaruhinya. Jika seorang penganut kepercayaan meminta pengakuan terhadap Tuhannya atau ibadahnya, seorang yang nasionalis juga meminta pengakuan terhadap budaya bangsanya atau etnisnya.

\section{Pemikiran dan Ideologi Mishima Yukio}

Mishima dikenal oleh masyarakat Jepang sebagai sastrawan berhaluan kanan (uyoku). Uyoku (右翼) adalah orang-orang yang yakin pada keunggulan ras Jepang, tradisionalis, anti komunisme, dan menjunjung tinggi sistem kekaisaran Jepang. Di dalam artikel Kazumasa Iha yang berjudul "Mishima Yukio and His Political Ideas" 2 , disebutkan bahwa Mishima berkeyakinan bahwa kaisar menempati kedudukan yang sangat penting dan merupakan sosok tertinggi dalam kebudayaan. Akan tetapi, setelah Jepang kalah dalam Perang Dunia II, kedudukan kaisar terdegradasi karena hanya dijadikan sebagai simbol pemersatu saja. Mishima ingin mengembalikan martabat kaisar dengan menempatkan kaisar ke dalam posisi seperti semula sebagaimana yang kedudukan kaisar pada era sebelumnya.

Mishima dikenal sebagai novelis yang ultranasionalis. Kecintaannya terhadap Jepang diekspresikannya dengan semangat mengembalikan Jepang kepada bentuk aslinya. Kesakralan kedudukan kaisar dan semangat bushido dianggapnya sebagai hal yang mutlak bagi eksistensi Jepang.

"Marilah kita kembalikan Jepang ke bentuk murninya dan biarkan kami mati. Apakah kalian akan menghargai hidup dan membiarkan semangat kebangsaan mati? Kami akan menunjukkan suatu nilai tinggi yang jauh lebih mulia ketimbang penghormatan pada kehidupan. Bukan kebebasan. Bukan demokrasi. Hanya

\footnotetext{
${ }^{2}$ Diunduh dan diterjemahkan oleh penulis dari http://nels.nii.ac.jp/els/110001039401.pdf
} 
Jepang, Jepang, tanah air sejarah dan tradisi. Jepang yang kita cintai,"3.

Mishima yang ultranasionalis dan sangat menghargai warisan budaya Jepang itu dipertanyakan oleh banyak kritikus karena pengakuannya yang berempati terhadap pembakar Kinkakuji. Ketika Kinkakuji ditulis (1956), Jepang sudah mulai pulih dari keterpurukannya secara ekonomi. Akan tetapi, Mishima menganggap bahwa Jepang berada dalam imoralitas karena memakai konstitusi yang tidak dibuat oleh Jepang sendiri dan menempatkan kaisar tidak pada tempatnya yang seharusnya.

\section{Kaitan Antara Thumos dan Ideologi Mishima}

Keinginan untuk pengakuan bersumber dari dua hal yaitu: agama atau religi dan nasionalisme. Penganut suatu kepercayaan menilai segala sesuatu berdasarkan pertimbangan kesucian menurut agamanya. Orang yang nasionalis juga menilai sesuatu berdasarkan pertimbangan pandangan nasionalnya atau etnisnya. Semua itu bersembunyi dari sesuatu yang dinamakan dengan ideologi. Ideologi tersebut, yang tidak semuanya rasional, menjadi sumber dari pertarungan pengakuan yang seringkali menjadi sumber konflik.

Bagi Mishima Yukio, agamanya adalah bushidoo yang merupakan nilai etik samurai, sebuah ideologi pejuang aristokrat Jepang yang menekankan pada pertaruhan jiwa raga untuk suatu tujuan yang telah ditentukan untuk para samurai tersebut. Sedangkan nilai ultranasionalisme yang diinginkan Mishima untuk diakui oleh masyarakat Jepang adalah penjagaan terhadap nilai-nilai tradisional Jepang, yaitu mengenai kedudukan dan konsep mengenai kaisar Jepang.

Di dalam keinginan yang bersifat thumos, kompromi tidak mempunyai tempat di dalamnya. Karena itu dalam

\footnotetext{
${ }^{3}$ Diunduh dan diterjemahkan oleh penulis dari http://en.wikipedia.org/wiki/Yukio_Mishima
}

pencarian "keadilan", thumos dapat menggerakkan seseorang menjadi fanatik, obsesif, dan pembenci karena kebanggaan terhadap nilai-nilainya tidak diikuti oleh pengakuan orang lain terhadapnya. Ekspresi thumos yang sangat kuat menimbulkan dorongan untuk mengalahkan insting terkuat alami manusia, yaitu insting kehidupan. Setelah Jepang kalah perang dan sebagai akibatnya kedudukan kaisar menjadi terdegradasi, thumos sebagian besar generasi Mishima terkoyak. Hal ini tercermin pada novel Kinkakuji karya Mishima yang berlatar kondisi sosial masyarakat Jepang setelah perang. Terdapat kesamaan antara pandangan-pandangan Mishima Yukio dengan Mizoguchi, protagonis dalam novel Kinkakuji. Dalam tulisan berikut akan dibeberkan beberapa ekspresi thumos Mishima yang terekspresikan dalam novel Kinkakuji melalui tokoh-tokohnya, khususnya tokoh protagonisnya yaitu Mizoguchi.

\section{Ekspresi Thumos Mishima dalam Novel Kinkakuji}

Berikut beberapa ekspresi thumos Mishima dalam novel Kinkakuji.

\subsection{Mengenai Keputusasaan Bangsa Jepang Setelah Perang}

Setelah Jepang menyerah tanpa syarat kepada Amerika, situasi dilematis menerpa Jepang. Jepang dihadapkan pada keadaan yang mengharuskannya tunduk dan mengikuti segala aturan yang diberikan oleh Amerika. Jepang yang sebelumnya mandiri dan bertindak sesuai dengan tradisi bangsanya sendiri menjadi Jepang yang didikte oleh bangsa lain. Sebelumnya, bangsa Jepang sangat yakin dengan keunggulan ras, tradisi, dan budayanya. Pengalaman sejarah berkali-kali membuat orang Jepang percaya bahwa Jepang adalah negara yang superior dan negara yang mendapat bantuan dari para dewa. Keyakinan kuat itu diperkirakan mulai menguat ketika bangsa Mongol gagal total dalam menginvasi Jepang. Pada saat itu, kapal-kapal Mongol terkena angin topan dalam perjalanannya menuju Jepang melalui 
Laut Jepang, sehingga setelah sampai di daratan Jepang pasukan Mongol dengan mudah dipukul mundur oleh Jepang. Orang Jepang percaya bahwa angin topan itu dikirim oleh dewa, sehingga muncullah terminologi kamikaze ( 神風) ${ }^{4}$. Pada zaman yang lebih modern, Jepang juga menjadi pemenang dalam Perang melawan Cina, Korea, dan Rusia. Bangsa Jepang, khususnya sebelum Perang Dunia II sangat percaya bahwa Kaisar Jepang adalah keturunan dewa.

Setelah dua kota di Jepang yaitu Nagasaki dan Hiroshima di bom oleh Amerika, Kaisar Hirohito mengumumkan kekalahan Jepang ke seluruh kota-kota di Jepang melalui radio. Pada saat itu, rakyat Jepang untuk pertama kalinya mendengar suara kaisar yang mereka puja. Akan tetapi, yang mereka dengar adalah sesuatu yang tidak disangka-sangka dan membuat terkejut rakyat Jepang. Ketika itu, kelaparan melanda hampir semua penjuru Jepang dan hal itu diperparah dengan pengumuman kekalahan itu.

Mishima mempunyai pandangan mengenai etik yang berpusat pada penghormatan secara penuh terhadap kaisar yang memiliki sifat keilahian/kedewaan. Akan tetapi, kaisar yang mereka bela matimatian telah mengkhianati mereka melalui Ningen-Sengen ${ }^{5}$ tahun 1946, suatu deklarasi

\footnotetext{
${ }^{4}$ Kami dalam bahasa Jepang berarti dewa, dan kaze adalah angin. Istilah ini berasal dari nama angin topan dalam legenda yang disebut-sebut telah menyelamatkan Jepang dari invasi Mongol pada tahun 1281. (diunduh dan diterjemahkan dari id.wikipedia.org/wiki/Kamikaze)

5 Ningen Sengen adalah deklarasi/maklumat kemanusiaan. Maklumat ini disampaikan secara langsung oleh Kaisar Hirohito disiarkan melalui radio nasional Jepang pada 1 Januari 1946. Nama lain dari ningen sengen adalah ShinNippon kensetsu ni kan suru shōsho (新日本建 設に関する詔書), yang berarti pembatalan perjanjian untuk rekonstruksi Jepang yang baru. Di dalam pidatonya Hirohito mengatakan "hubungan kami dan rakyat kami selalu didasarkan pada kepercayaan dan kasih sayang dan tidak tergantung pada legenda dan mitos. Adalah suatu konsepsi yang salah bahwa kaisar bersifat ketuhanan dan bahwa rakyat Jepang
}

yang mengubah figur otoritas kedewaan ke dalam suatu status manusia biasa di dalam negara.

Hal di atas adalah nilai-nilai atau thumos yang dimiliki Mishima. Di dalam novel ini, Mizoguchi dilukiskan sebagai korban dari dunia jahat yang selalu mengkhianatinya, dan hal itu tercermin dalam keputusasaan anak muda itu terhadap Kinkakuji yang dipuja keindahannya yang selalu menjadi rintangan dalam hidupnya. Dunia yang jahat tersebut dapat ditafsirkan sebagai keadaan zamannya telah kehilangan sumber moral tradisionalnya. Kinkakuji dalam hal ini menyimbolkan keindahan nilai-nilai tradisional Jepang tersebut.

Mishima tidak puas dengan Jepang modern dan merasa bahwa tradisi Jepang masa lalu terlalu cepat ditinggalkan. Mishima percaya bahwa degradasi moral yang ia rasakan di dalam masyarakat Jepang sehabis perang diakibatkan oleh pengingkaran status kedewaan Kaisar Hirohito karena tekanan dari Amerika Serikat dan sekutunya. Bagi Mishima hilangnya status keilahian/kedewaan kaisar berarti hilangnya jiwa bangsa Jepang, yang berakibat pada kekacauan sosial sebagai hasilnya.

Di dalam novel Kinkakuji, perasaan keputusasaan bangsa Jepang terungkap melalui pernyataan Mizoguchi berikut.

敗戦は私にとっては、こうした絶望の 体験に他ならなかった。今も私の前に は、八月十五日の焔のような夏の光が 見える。（Kinkakuji, 1960: 69）

"Kekalahan nusa dan bangsaku bagiku adalah pengalaman keputusasaan seperti itu. Bahkan kini aku masih dapat membayangkan di hadapanku cahaya musim panas yang mirip api pada hari kekalahan itu, tanggal 15 Agustus"6.

lebih superior dibanding ras yang lain dan ditakdirkan untuk menguasai dunia". (diunduh dan diterjemahkan dari http://en.wikipedia.org/wiki/Humanity_Declaration).

${ }^{6}$ Perang Pasifik yang menyeret Jepang ke dalam Perang Dunia II berakhir pada 15 Agustus 1945 dan perjanjian menyerahnya Jepang ditandatangani oleh wakil dari sekutu yaitu Jendral Douglas McArthur dan Jepang diwakili 
Dalam kalimat "Haisen wa watashi ni totte wa kooshita zetsuboo no taiken ni hoka naranakatta", kata "kooshita zetsuboo" yang artinya "keputusasaan seperti ini" merujuk pada pada kalimat sebelumnya yaitu

「金閣と私との関係は絶たれたんだ」

と私は考えた。「これで私と金閣とが 同じ世界に住んでいるという夢想は崩 れた。またもとの、もとよりももつと 望みのない事態がはじまる。美がそこ におり、私はこちらにいるという事態。 この世のつづくかぎり渝わらぬ事態...」

(Kinkakuji, 1960: 69)

"Ikatan antara Kinkakuji dengan aku sudah terputus," kataku dalam hati. "Kini anggapan bahwa Kinkakuji itu dan aku hidup dalam sebuah dunia yang sama, sudah hancur. Kini aku berada dalam keadaan yang lebih buruk daripada keadaan dulu. Suatu keadaan, dimana aku berada di satu pihak sedangkan di pihak lain berada keindahan. Suatu keadaan yang tidak akan mungkin berubah selama dunia ini ada."

Kutipan di atas adalah ungkapan keputusasaan Mizoguchi yang diakibatkan Kinkakuji yang beroposisi dengannya. Dia merasa tidak dapat menyatu lagi dengan keindahan Kinkakuji. Inilah fase ketika Mizoguchi merasa sangat putus asa dengan harapan dan nilainya. Dari dua kutipan di atas dapat disimpulkan bahwa ada persamaan perasaan putus asa yang dialami oleh Mizoguchi terhadap keindahan Kinkakuji dan hilangnya nilai tradisional Jepang karena kekalahan Jepang dalam Perang Dunia II. Perasaan Mizoguchi yang hampa karena merasa dikhianati Kinkakuji dilukiskannya dengan kalimat "kono yo no tsuzuku kagiri kawaranu jitai" (Suatu keadaan yang tidak akan mungkin berubah selama dunia ini ada ). Kalimat tersebut bernada keputusasaan yang sangat dalam dan memiliki persamaan dengan perasaan Mishima Yukio yang merasakan kehampaan hidup karena dikhianati oleh zamannya.

oleh Mamoru Shigemitsu diatas kapal USS Missouri (diunduh dari http://id.wikipedia.org/wiki/Perang_Pasifik)
"Lantaran beberapa urusan pribadi, aku menyerahkan hidupku sebagai kesia-siaan. Hal itu muncul bersama teror besar yang aku ingat tentang kehampaan hidup keseharianku yang aku alami untuk beberapa tahun setelah kekalahan total itu"" .

Kesamaan perasaan keputusasaan tersebut mungkin sekilas adalah kebetulan belakan. Akan tetapi, menurut pendapat penulis hal tersebut dapat ditafsirkan sebagai gambaran thumos Mishima yang terkoyak dan gambaran keputusasaan yang dialami generasinya terhadap kondisi Jepang paska kekalahan Jepang dalam Perang Dunia II.

Oleh karena itu dapat disimpulkan bahwa melalui novel Kinkakuji, Mishima ingin mengungkapkan bahwa nilai tradisional Jepang sudah kehilangan maknanya setelah Jepang terpaksa mengikuti konstitusi baru yang dibentuk Amerika. Kebencian dan cinta yang berpadu di dalam diri Mizoguchi terhadap Kinkakuji sebelum dan setelah perang mencerminkan perasaan ambivalen masyarakat Jepang, terutama generasinya Mishima, terhadap negara Jepang dan kaisarnya yang mereka bela dengan mati-matian dalam Perang Dunia II. Thumos yang dimiliki sebagian besar generasi Mishima terpusat pada nilai patriotik yang sangat besar dalam membela kaisar dan negaranya. Akan tetapi setelah perang berakhir dan kaisar Jepang mengumumkan status barunya, thumos sebagian besar generasi Mishima terkoyak. Koyakan terhadap nilai tersebut bukan dari pihak lain, melainkan dari kaisar Jepang yang justru menjadi salah satu nilai penting dalam thumos generasi Mishima. Hal ini mengakibatkan ambivalensi di dalam generasi Mishima terhadap nilai-nilai yang dipunyainya.
7 Kazumasa, Iha. 1972. "Mishima Yukio and His Political Ideas". Okinawa-Kokusai University bulletin of linguistics and literature, hal 94. 


\subsection{Mengenai Pembebasan Jepang dari Sistem Kokutai ${ }^{8}$ dan Militerisme}

Dalam novel Kinkakuji, terdapat kutipan yang menunjukkan pemikiran Mizoguchi tentang kekalahan Jepang dalam Perang Dunia II. Bagi Mizoguchi, pandangan bahwa kekalahan Jepang merupakan suatu pembebasan adalah suatu kesalahan. Berikut adalah perkataan Mizoguchi mengenai pandangan tersebut.

私にとって、敗戦が何であった かを言っておかなくてはならない。そ れは解放ではなかった。断じて解放で はなかった。不変のもの、永遠なもの、 日常のなかに融けこんでいる仏教的な 時間の復活に他ならなかった。（7273 ページ)

"Aku harus jelaskan apa arti kekalahan bangsa Jepang ini bagiku. Ini bukanlah pembebasan. Ini bukanlah pembebasan. Tidak, sama sekali bukanlah pembebasan. Ini tidak lain daripada kembali pada kebiasaan Budhis yang abadi tak berubah-ubah, yang berpadu dengan kehidupan kita sehari-hari”.

Paradoks Jepang setelah Perang Dunia II adalah bahwa bersamaan dengan keberhasilan rekonstruksi nasional dan mulai makmurnya perekonomian Jepang pada tahun 50-an, sukses ini hanya terjadi karena adanya adopsi dari ideologi barat, pembatasan kemiliteran yang diawasi oleh Amerika Serikat dan juga konstitusi negeri yang dibuat setelah penyerahan Jepang. Jepang diduduki oleh militer Amerika

\footnotetext{
${ }^{8}$ Kokutai (国 体) berasal dari bahasa China guoti ( 國 體) yang berarti bentuk pemerintahan negara). Sejarah kokutai dimulai dari periode Edo ketika keshogunan Tokugawa berkuasa di Jepang. Aizawa Seishisai (会沢正志斎, 1782-1863) adalah pemimpin Sekolah Mitogaku (水戸学) yang menyokong restorasi kekaisaran Jepang. Dia mempopulerkan kata kokutai di dalam Shinron ( 新 論) pada 1825 dan juga memperkenalkan slogan Sonnō jōi ("Lindungi kaisar dan usir kaum barbar"). (diunduh dan diterjemahkan dari http://en.wikipedia.org/wiki/Kokutai).
}

Serikat sejak saat Jepang menyerah sampai 1952 dan dipaksa untuk membuat suatu konstitusi baru yang membasmi institusi kokutai dan kekuasaan Kaisar. Amerika kemudian menggantikannya dengan model demokrasi Barat dimana Kaisar hanya ditempatkan sebagai pemimpin boneka. Konstitusi yang baru juga melarang Jepang dari mempunyai kekuatan militer yang ofensif dan hanya dibolehkan untuk membela diri (Jieitai).

Pendudukan Amerika terhadap Jepang seketika dimulai setelah Perang Dunia II dan bertahan selama enam tahun delapan bulan. Tujuan utamanya adalah demilitarisasi, desentralisasi dan demokratisasi Jepang. Diantara perubahan yang diperkenalkan setelah Perang Dunia II adalah persamaan kedudukan laki-laki dan wanita, pemeriksaan secara seksama terhadap Diet (parlemen Jepang) dan mendukung hak-hak pekerja untuk membela kepentingannya. Selain itu, wanita-wanita Jepang diberi hak untuk memilih, tahanan politik dibebaskan, perserikatan diorganisir, pembentukan parpol, liberalisasi pendidikan, pembolehan terhadap monopoli industri dan jaminan atas kebebasan terhadap pers. Kemudian, Artikel 9 dari konstitusi melarang Jepang dari semua aktivitas militer. Disebutkan bahwa Jepang selamanya meninggalkan peperangan sebagai hak/ kebenaran kedaulatan dan penggunaan ancaman dari kekuatan angkatan bersenjata tidak pernah akan digunakan lagi ${ }^{9}$.

Semua perubahan itu membuat masyarakat Jepang menjadi lebih merasa aman dan nyaman. Hak-hak sipil menjadi lebih diperhatikan dan peningkatan ekonomi juga mulai dirasakan. Oleh karena itu, sebagian besar masyarakat Jepang merasa kekalahan Jepang di dalam PD II adalah keuntungan bagi mereka. Amerika dianggap telah membebaskan Jepang dari militerisme dan mendorong Jepang ke arah demokrasi yang dianggap lebih baik. Bagi mereka, kekalahan membawa berkah karena tercipta

\footnotetext{
${ }^{9}$ Diunduh dari

http://factsanddetails.com/japan.php?itemid=526 \& catid $=16 \&$ subcatid $=110$
} 
satu sistem atau tatanan kehidupan berbangsa dan bernegara yang lebih baik. Hak-hak sipil mereka lebih diperhatikan dan kehidupan perekonomian mereka juga ikut mengalami peningkatan. Mereka tidak khawatir lagi Jepang akan terjerumus lagi dalam peperangan yang membawa mereka pada kesengsaraan dan penderitaan hidup.

Setelah kekalahan itu, kebanyakan orang-orang Jepang merasa dibebaskan dari militerisme dan sistem kokutai, tetapi Mizoguchi tidak menganggap kekalahan itu sebagai pembebasan. Penolakan Mizoguchi tentang pendapat bahwa kekalahan Jepang adalah pembebasan menggunakan analogi yang didasarkan pada pemikiran Buddhisme. Di dalam kehidupan pasti ada dua sisi yang saling berlawanan dan bergantian secara wajar. Ada siang, ada malam; ada perempuan ada laki-laki; suatu saat mengalami kekalahan, dan pada suatu saat mengalami kemenangan. Kekalahan tersebut bagi Mizoguchi seharusnya disikapi seperti itu.

Seperti yang telah disebutkan sebelumnya, Mishima yang ultranasionalis mempunyai thumos atau keinginan untuk diakui nilai-nilainya. Nilai-nilai tersebut terdapat dalam pengakuan terhadap nilainilai tradisional Jepang. Kaisar Jepang dan kokutai merupakan dua bentuk nilai yang absolut bagi seorang ultranasionalis seperti Mishima.

Ekspresi thumos yang dimiliki Mishima terekspresikan di dalam ucapan Mizoguchi bahwa kekalahan Jepang bukanlah pembebasan, Mishima mengungkapkan bahwa thumosnya menyatakan ketidaksetujuannya dengan pendapat sebagian masyarakat Jepang di atas yang menganggap bahwa kekalahan Jepang adalah sebuah pembebasan. Bagi Mishima yang ultranasionalis, nilai-nilainya yang ingin mendapat pengakuan dari orang lain adalah bukan terletak pada harta, kekayaan atau kemakmuran, tetapi pada penegakan nilai-nilai tradisi Jepang. Bagi Mishima, kekalahan bangsa Jepang tidak seharusnya diikuti dengan meninggalkan tradisi Jepang dan mengikuti sepenuhnya nilai-nilai dari Barat. Kalah dan menang adalah hal yang biasa, dan merupakan bagian dari kehidupan manusia sehariharinya.

Dari uraian di atas dapat disimpulkan bahwa penggunaan terminologi pembebasan terhadap kekalahan bangsa Jepang adalah suatu hal yang salah. Pembasmian sistem kokutai dan bentuk asli kekaisaran Jepang adalah suatu hal yang tidak bisa dianggap sebagai pembebasan. Dengan pengungkapan hal tersebut dalam novel Kinkakuji, Mishima ingin mengkritik sebagian masyarakat Jepang yang merasa telah terbebas perang dan dari sistem kokutai dan kekuasaan kaisar yang mutlak.

\subsection{Mengenai Ketidakbermaknaan Hidup}

Dalam novel Kinkakuji diceritakan bahwa Mizoguchi terbelenggu akan keindahan Kinkakuji dalam pikirannya. Belenggu tersebut dimulai ketika Kinkakuji tidak hancur dalam Perang Dunia II. Mizoguchi justru menginginkan Kinkakuji hancur dalam Perang Dunia II. Bersamaan dengan kehancuran Kinkakuji, Mizoguchi berharap dia berada di dalam Kinkakuji dan mengalami kematian yang bermakna, karena ketika hal itu terjadi maka berarti telah terjadi penyatuan antara dirinya dengan keindahan Kinkakuji.

Perasaan Mizoguchi yang menginginkan kematian dalam perang tersebut mirip dengan apa yang dicitacitakan oleh Mishima Yukio dan sebagian besar pemuda Jepang pada masa perang. Masyarakat Jepang pada saat itu rela hidupnya mereka korbankan demi kaisar dan negaranya. Kematian bagi mereka bukanlah suatu hal yang ditakuti. Dengan mati karena membela kaisar dan negaranya, maka kematian mereka menjadi bermakna.

Akan tetapi, setelah Jepang kalah dalam perang, kehidupan mereka menjadi kurang mempunyai makna. Kaisar Jepang yang mereka puja menanggalkan status kedewaannya sebagaimana yang Amerika inginkan. Di dalam novel Kinkakuji, hal tersebut memang tidak secara tersurat diungkapkan oleh Mishima Yukio. Mizoguchi hanya dilukiskan sebagai orang yang kecewa karena dia tidak mati di dalam 
kehancuran Kinkakuji karena pemboman oleh pesawat-pesawat Amerika. Akan tetapi, ada persamaan perasaan kekecewaan antara Mizoguchi dengan perasaan kecewa Mishima Yukio yang mengarang novel tersebut, apabila dikaitkan dengan zaman ketika Jepang berada di puncak peperangannya dengan Amerika.

Mishima adalah seorang novelis yang mencita-citakan "romantisme kematian untuk Kaisar". Dalam sebuah kesempatan, Mishima mengatakan sebagai berikut

"Itu adalah waktu yang langka (1944-1945), ketika nihilismeku dan nihilisme masyarakat tentang nasib dengan sempurna terhubung" 10

Mishima sangat menyesali hidupya karea ia luput/kehilangan kesempatan untuk mati pada masa itu, dan ia menganggap hari-harinya setelah perang sebagai sisa hidup yang seharusnya telah usai. Kinkakuji merupakan cerminan kerinduannya terhadap nilai-nilai etik dan tradisional Jepang yang dinilainya telah hilang, di mana kaisar adalah yang mempersatukan kekuatan dan merupakan pusat dari kebudayaan Jepang. Dengan penggunaan Kinkakuji sebagai lambang Jepang di masa lampau, melalui Mizoguchi yang merupakan tokoh utama dalam novel Kinkakuji, Mishima ingin menguraikan sisa hidupnya yang berada di zaman yang telah mengkhianati kerinduannya terhadap Jepang di masa sebelumnya.

Kinkakuji juga dapat ditafsirkan sebagai lambang akan kerinduan Mishima terhadap Jepang di masa lampau yang berada di bawah naungan kedewaan kaisar Jepang dan sistem Kokutai. Sampai akhir peperangan, Kinkakuji tetap dibiarkan berdiri tegak oleh pihak sekutu, sebagaimana halnya kaisar Jepang yang tetap dibiarkan menjadi kaisar, walaupun hanya sebagai simbol saja. Mishima sangat kecewa terhadap keputusan Kaisar Hirohito yang menanggalkan status kedewaannya.

\footnotetext{
${ }^{10}$ Diunduh dari

http://findarticles.com/p/articles/mi_m0403/is _n2_v39/ai_14773421/?tag=content;col1).
}

Mishima mengungkapkan hali ini dengan perasaan kekecewaan tokoh utamanya yaitu Mizoguchi yang menganggap bahwa perang telah mengkhianatinya karena telah membiarkan Kinkakuji tetap tegak dan dirinya tetap hidup.

Sebagaimana yang telah disebutkan sebelumnya, menurut Mishima hilangnya status keilahian/kedewaan kaisar adalah berarti hilangnya jiwa bangsa Jepang, yang berakibat pada kekacauan sosial sebagai hasilnya.

Kondisi Jepang pada saat perang dan sesaat setelah perang merupakan keadaan yang terburuk sepanjang sejarahnya. Di Jepang terjadi krisis pangan yang sangat memprihatinkan. Banyak orang yang menjadi putus asa karena kekurangan makan. Di pinggir-pinggir jalan, banyak orang yang mengemis meminta makanan. Apapun dilakukan untuk mendapatkan makanan. Seluruh kota besar kecuali Kyoto menjadi tumpukan puing-puing karena pemboman yang dilakukan Amerika. Inflasi sangat tinggi dan keadaan perekonomian sangat terpuruk. Meskipun pada tahun berangsur-angsur Jepang sudah mulai menikmati kemajuan dalam perekonomiannya, Mishima merasakan zaman itu sebagai zaman yang penuh dengan kehampaan spiritual.

Bagi Mishima, pengaruh yang diakibatkan karena perubahan status kaisar Jepang mempunyai efek yang dalam bagi jiwa bangsa Jepang. Thumos yang dimiliki Mishima dan generasinya menjadi kehilangan sumbernya. Hal inilah yang kemudian menyebabkan Mishima menyebut zaman setelah perang adalah zaman yang dipenuhi dengan teror. Di dalam suatu tulisannya pada tahun 1955, Mishima mengungkapkan perasaannya sebagai berikut.

"Lantaran beberapa urusan pribadi, aku menyerahkan hidupku sebagai kesiasiaan. Hal itu muncul bersama teror besar yang aku ingat tentang kehampaan hidup keseharianku yang aku alami untuk beberapa tahun setelah kekalahan total itu. Sepanjang periode 1946 sampai 1948, yang seharusnya merupakan kejayaan masa mudaku (periode ini paruh pertama dari 
umurnya yang duapuluhan), saya merasa lebih dekat ke kematian. Masa depan tidak memberi harapan apapun kepadaku..... Aku pikir aku harus lebih dulu menyatakan diriku dan hidupku seperti mereka tentu saja, tetapi pernyataan diriku yang muncul;menjadi berkebalikan dengan waktu, di antara kecenderungan sosial akan pembinasaan dan peniadaan dalam Jepang sehabis perang" $"$.

Dalam novel Kinkakuji, Mishima menggambarkannya dalam sosok Mizoguchi sebagai orang yang merasakan ketidakbermaknaan hidup, mengalami kehampaan spiritual dan merasa terkhianati. Ketika seseorang mengalami kehampaan spiritual dan mengalami ketidakbermaknaan hidup, dia akan cenderung untuk mencari hal yang dapat mengisi ruang kosong itu di dalam hatinya. Dorongan-dorongan untuk berbuat jahat juga cenderung untuk keluar seperti yang dirasakan pula oleh Mizoguchi berikut.

父の死も、母の貧窮も、ほとん ど私の内面生活を左右しなかった。私 はただ災禍を大破局を、人間的規模を 絶した悲劇を人間も物質も、醜いもの も美しいものも、おしなべて同一の条 件下に押しつぶしてしまう巨大な天の 圧搾機のようなものを夢みてみた。

$$
\text { (52ページ) }
$$

"Kematian ayah dan kemiskinan ibu sama sekali tidak menyentuh batinku sama sekali. Yang kuimpi-impikan ialah semacam kompresor langit raksasa yang akan menurunkan malapetaka, musibah dan tragedi manusia, yang akan menghimpit seluruh manusia dan semua benda sampai hancur, baik yang bagus maupun yang buruk".

$$
\begin{array}{ccr}
\text { Kutipan } & \text { di atas } & \text { adalah kutipan } \\
\text { seseorang } & \text { yang } & \text { mengalami }
\end{array}
$$

${ }^{11}$ Kazumasa, Iha. 1972. "Mishima Yukio and His Political Ideas". Okinawa-Kokusai University bulletin of linguistics and literature, hal 94. ketidakbermaknaan hidup yang paling dalam. Ketika seseorang putus asa dan tidak menemukan solusi dalam kehidupannya, bunuh diri adalah solusi tercepat yang sering terbersit di dalam diri manusia. Jika seseorang kehilangan thumos, maka dia akan kehilangan esensinya sebagai seorang manusia. Manusia seperti itu, dengan nasibnya yang tidak merasa malu karena ketidakmampuannya untuk mengungguli atau menyamai manusia lainnya, secara perlahan ingin "berhenti" sebagai manusia. Keadaan seperti itulah yang dialami oleh Mizoguchi dalam kehidupannya. Mizoguchi menginginkan kematiannya dan juga semua hal yang ada di dunia.

Setelah perang berakhir, pikiran destruktif Mizoguchi tidak menjadi hilang tetapi malah menjadi semakin berkembang dan bertambah.

$$
\text { 『これが俗世だ』と私は思った。 }
$$
『戦争がおわって、この灯の下で、 人々は邪悪な考えにかられている。多 くの男女は灯の下で顔を見つめ合い、 もうすぐ前に迫った、死のような行為 の匂いを嗅いでいる。この無数の灯が 悉く邪まな灯だと思うと、私の心は慰 められる。どうぞわが心の中の邪贯が、 繁殖し、無数に殖え、きらめきを放っ て、この目の前のおびただしい灯と、 ひとつひとつ照応を保ちますように！

(Kinkakuji, 1960: 76)

'Inilah, kataku dalam hati, alam duniawi. Sejak peperangan berakhir, orangorang dikemudikan oleh pemikiran jahat. Pasangan tidak terhitung jumlahnya sedang saling menatap di bawah cahaya itu, dan di dalam lubang hidung mereka terdapat bau perbuatan yang sama dengan kematian, yang sedang menekan secara langsung. Di pikiranku semua cahaya itu semua bersifat merusak, maka hatiku jadi terhibur. Tolong biarkan kejahatan itu ada di dalam hatiku dan terus meningkat sedemikian rupa".

Kutipan di atas adalah pemikiran Mizoguchi melalui pengamatannya terhadap orang-orang di sekitarnya setelah perang 
berakhir. Menurut penulis, kutipan di atas bukan sebatas pemikiran unik Mizoguchi saja. Pemikiran Mizoguchi tersebut adalah gambaran thumos yang terkoyak dan juga permakluman Mishima terhadap generasinya yang dikecewakan oleh keadaan yang dialami oleh negaranya.

\section{Simpulan}

Cerita fiksi di dalam novel Kinkakuji merupakan salah satu contoh karya sastra yang mempunyai pertalian yang erat dengan realitas sosial yang terjadi di dalam masyarakat Jepang pada saat itu. Novel Kinkakuji dapat dianggap sebagai sindiran dan kritik penulisnya terhadap kondisi sosial masyarakat Jepang setelah Jepang mengalami kekalahan di dalam Perang Dunia II.

Mishima adalah orang yang menginginkan masyarakat Jepang selalu memegang teguh nilai-nilai tradisional Jepang. Setelah Jepang kalah dalam Perang Dunia II, nilai-nilai itu pun dinilainya telah hancur. Thumos seorang ultranasionalis seperti Mishima terekspresikan di dalam pikiran-pikiran dan para tokoh di dalamnya, khususnya dalam diri Mizoguchi, tokoh utama dalam novel Kinkakuji.

\section{DAFTAR PUSTAKA}

Kazumasa, Iha. 1972. "Mishima Yukio and His Political Ideas". OkinawaKokusai University bulletin of linguistics and literature 1(1) hlm 81-104. Diunduh dari http://ci.nii.ac.jp/els/11000103940 1.pdf?id=ART0001205246\&type= pdf\&lang=en\&host=cinii\&order no $=\& p p v \_t y p e=0 \&$ lang_sw $=\&$ no $=1293592501 \& \mathrm{cp}=$

Laurenson, Diana dan Alan Swingewood. 1972. Sociology of Literature. London : Paladin

Yukio, Mishima. 1960. Kinkakuji. Tokyo: Shinchosha 